\title{
Young children's citizenship membership and participation: comparing discourses in early childhood curricula of Australia, New Zealand and the United States
}

\section{Louise Gwenneth Phillips, Jenny Ritchie \& Jennifer Keys Adair}

To cite this article: Louise Gwenneth Phillips, Jenny Ritchie \& Jennifer Keys Adair (2020) Young children's citizenship membership and participation: comparing discourses in early childhood curricula of Australia, New Zealand and the United States, Compare: A Journal of Comparative and International Education, 50:4, 592-614, DOI: 10.1080/03057925.2018.1543578

To link to this article: https://doi.org/10.1080/03057925.2018.1543578

\section{曲 Published online: 03 Dec 2018.}

Submit your article to this journal $\pi$

Џlll Article views: 511

Q View related articles $\widetilde{ }$

View Crossmark data $₫$ 


\title{
Young children's citizenship membership and participation: comparing discourses in early childhood curricula of Australia, New Zealand and the United States
}

\author{
Louise Gwenneth Phillips (iD) ${ }^{a}$, Jenny Ritchie (D) ${ }^{b}$ and Jennifer Keys Adair ${ }^{c}$ \\ aSchool of Education, The University of Queensland, St Lucia, Australia; 'b 5 chool of Education, Victoria \\ University of Wellington, Wellington, New Zealand; 'College of Education, The University of Texas at \\ Austin, Austin, TX, USA
}

\begin{abstract}
Recognition of young children as citizens is relatively new in sociology, with translation emerging into education. Discourses of children and childhood shape ideas of young children as citizens and national discourses of citizenship frame what civic participation can be. The authors analysed national early childhood education curricula frameworks of Australia, New Zealand and the United States to understand how discourses authorise constructions of children as citizens and opportunities for young children's civic participation. They sought to locate how children are positioned as citizens and what opportunities there are for young children's citizenship participation in national early childhood curricula documents of Australia, New Zealand and the United States. Illustrative examples of children's citizenship membership and participation from the three nations' early childhood curricula were critically read to locate how prevalent discourses of children, childhood and citizenship in each nation define children as citizens and shape possibilities for citizenship participation for young children.
\end{abstract}

\section{KEYWORDS}

Citizenship education; discourse analysis; early childhood; curricula; young children

Children and young people are members of society; they are rights holders and active contributors (United Nations 1989). Attention to civic learning and action is often aimed at secondary-school students and is largely focused on the maintenance of social and political institutions and the social integration of children and young people into the current political system (Flanagan 2012). However, young children's civic learning and action receives varying degrees of attention in national early childhood curriculum frameworks. We are early childhood education scholars who see civic learning and action as a lifelong continuum in which all humans are learning and contributing in ways that are appropriate to their life-stage. Broadly, we agree with Tijsterman (2014) that citizenship refers to 'what it means to be a political agent' (178), and embrace Mouffe's (1991) proposition of radical democratic citizenship in which citizenship is considered to be about political identity in the public arena. From this position, we argue that young children should be recognised as political agents. 
In this article, we consider how civic learning and action from a participatory model that acknowledges the existence of citizenship responsibilities (Peterson 2011) might be understood for young children in early childhood education settings as the foundation of citizenship education. We do so through discourse analysis of references to citizenship membership and participation of early childhood curricula (for children from birth to five years of age prior to schooling) in three democratic nations. This analysis extends upon earlier discussions in Compare which explore how socio-cultural and political contexts and national discourses of citizenship influence civics and citizenship curricula in Western democracies such as Australia, Canada, England and the United States (see Hughes, Print, and Sears [2010]), and the UK and Ireland (see Jerome [2017]). All these preceding discussions have focused on school curricula. We add to this body of work an analysis of citizenship curricula for early childhood in Australia, New Zealand and the United States. Following a 'most similar systems' design model for comparative studies (Anckar 2008), we selected Australia, New Zealand and the United States, as they are all Western democracies formed through British colonisation (though in different eras) of Indigenous peoples, via political systems emerging from the British parliamentary model (Rosenof 2010; Sawer, McLaren, and Kelly 2017). Australia and the United States follow a federalist system (so in these nations education is state governed), whilst New Zealand, a much smaller nation, is a regionalised unitary system. Though varying quite distinctly, there are common threads of commitment to democratic practices, and of nationhood building on waves of multicultural immigration. It is also important to note that there is much early childhood policy transfer between the three nations via international mechanisms such as the Organization for Economic Cooperation and Development (OECD). We thus noted variables that differ (Anckar 2008) in the representation of children and citizenship in the three sets of early childhood curricula.

Early childhood settings, such as childcare centres and kindergartens, provide a very different approach to education than schooling. Key principles that have historically informed early childhood education include being play-based, family-oriented, community-connected, child-centred and with a focus on fostering learning dispositions as opposed to imparting knowledge content (Chartier and Geneix 2006). In contemporary times, we recognise that early childhood settings are not immune to neo-liberal agendas of outcomes and performativity (Alcock and Haggerty 2013).

Early childhood settings are likely to be the first community spaces (polis) in which young children negotiate co-existence with unknown others (MacNaughton 2007) and thus provide a preliminary social atmosphere, away from family members, to experiment with and develop civic participation skills, knowledge, dispositions and attitudes. Yet, as Flanagan (2012) found in her commissioned review of empirical research on civic learning and action, there are almost no studies with elementary age children, let alone in early childhood, which she argues 'may reflect the challenges of conceptualising civic learning and civic action in this age group' (13). Children are widely excluded from 'universal citizenship' (Milne 2013, 29). Citizenship participation is considered to require reason, rationality and autonomy, which are attributes that many have considered children not to possess, because children are viewed as innocent and developing (Milne 2013) or not yet competent to exercise the rights and responsibilities of citizenship (Roche 1999). When children are mentioned in citizenship literature 'they usually are referred to as future citizens in discussions about citizenship education'; even those 
who argue for socially inclusive or differentiated citizenship rarely list children amidst the lists of marginalised disadvantaged social groups (Howe and Covell 2005, 57).

Scholars in the sociology of childhood (e.g. Corsaro [2005]; James, Jencks, and Prout [1998]) have challenged the positioning of young children as 'future' citizens, arguing that children are citizens of today. Whilst older children may have opportunities to be decision-makers and contributors to society, only recently has a case been made for the participation of younger children (e.g. Lansdown [2005]; MacNaughton, Hughes, and Smith [2008]). Studies in the sociology of childhood have positioned children as having competency and agency, inviting discussion of possibilities for defining children as active citizens and supporting children's practice as contemporary citizens (e.g. Howe and Covell [2005]; MacNaughton, Hughes, and Smith [2008]; Adair et al. [2017]). Further, citizenship scholars, such as Kymlicka (2001) also now argue for children to be recognised as citizens of today.

Some early childhood education practices take young children's capabilities for civic action seriously. This can be seen in anti-bias curriculum (Derman-Sparks 1989), through which young children are being taught to take action to resist bias, prejudice and discrimination. Reconceptualising early childhood scholars (e.g. Kessler and Swadener [1992]; Soto and Swadener [2005]) have argued for recognition of differences including those of culture, ethnicity, linguistics, gender, sexuality and ability, as well as for diversities in children's ways of being and knowing and contributing to society to be respected and valued. Early childhood education for sustainability (e.g. Davis [2010]) views children as 'agents of change for sustainability' (31). However, children's capacities to enact their civic agency are often regulated by context (e.g. see Phillips [2011]), such as the written curricula and resources that are in place, and the modelling and expectations of those adults who are responsible for educating children.

Based on these ideas of children's capabilities as active citizens, and Bellamy's (2008) three components (membership, rights and participation) of citizenship as a frame, we (the authors) sought to locate:

(1) How children are positioned as citizens; and

(2) What opportunities there are for young children's citizenship participation in the national early childhood curricula documents of Australia, New Zealand and the United States.

Rights are entangled in both questions: 'citizens are entitled to rights by virtue of membership, and as citizens, they participate in shaping these rights' (Hart, Richardson, and Wilkenfeld 2011, 774). National curricula were examined, as they carry 'historical and sociopolitical influences, values, cultural beliefs, and aspirations' (Wood and Hedges 2016, 389), thereby offering a site for exploring the embedded definition of national values, beliefs and aspirations of young children's citizenship membership and participation. We thus analysed illustrative curricula examples to identify how national discourses define children's citizenship membership and participation utilising critical discourse analysis, per Laclau and Mouffe's (1985) theory of discourse. We aimed to understand more fully how early childhood curricula construct meanings (MacLure 2003) of young children's citizenship. 
To set the scene for this curricula discourse analysis, we first explain the conceptual framework and methodology of discourse analysis. Then we look to discourses pertaining to the signifiers of the analysis: citizenship; children; and childhood. Dominant discourses of citizenship, children and childhood are discussed in relation to the nation-building of Australia, New Zealand and the United States, with regard to how these discourses influence the shaping of each nation's current early childhood curricula. Evidence of the ways in which children are described as citizens and of how opportunities for citizenship participation are promoted in the curricula documents are then compared and discussed. The article closes with a summation of the distinguishing hegemonic ideas influencing curriculum authorised citizenship education for young children in each nation.

\section{Approach to curricula analysis}

To understand how children are defined as citizens, and opportunities for children's citizenship participation in early childhood curricula in Australia, New Zealand and the United States, we located hegemonic national discourses of citizenship, children and childhood. Our approach to discourse analysis drew from Jorgensen and Phillips' (2002) description of discourse analysis informed by Laclau and Mouffe's (1985) theory of discourse. Drawing on Marxist theorising, Laclau and Mouffe acknowledge the political necessity of recognising hegemony, yet point out that the dichotomy of the oppressor and the oppressed 'seems to have exhausted its productivity' (151). Discourses are then understood to be constructed in an attempt to dominate the discursive field (the terrain of a constitution of a social practice) and fix meaning, though only partial fixation can be achieved, as there are constant struggles to fix meaning between discourses. Multiple discourses are recognised as being at play at any one time, exemplified through articulations being influenced by one discourse then being interrupted by another. To Laclau and Mouffe, the central problem is identifying the discursive conditions for the emergence of a collective action that challenges relations of subordination, such as what the discursive conditions that enabled feminism to rise in modern times and not in previous eras were. In the context of this early childhood curricula analysis, we sought to identify the discursive conditions that may welcome both young children as citizens and their civic participation by locating the discourses which attempt to dominate the fields of discursivity of citizenship, children, childhood and early childhood education. First, we provide a brief chronological historical account of dominant pertinent discourses of citizenship in the nation-building of the three colonial nations, followed by resounding respective national discourses on children and childhood framed within three waves of influence: colonisation; progressivism; and neoliberalism. We then describe the context in which each nation's early childhood curricula was developed.

\section{Discourses of citizenship in Australia, New Zealand and the United States}

Constructions of citizenship and nationhood grew out of mid-nineteenth century assertions of patriotism and shared language (Heater 1999). The United States, Australia and New Zealand are nations built on 'new world' phenomenon and discourse (Wanna 2008), and discourses stemmed from colonisation by the British. We explore 
how particular schools of thought have shaped the nation-building of the United States, Australia and New Zealand in chronological order of creation. The way citizenship membership and participation is defined is intimately linked to the kind of society and political community desired (Mouffe 1991).

The schools of thought of liberalism and republicanism are generally understood to have informed the American Founders in the nation-building of the United States following the American Revolution (Gibson 2000). The liberalist interest in liberty and individual rights (Mouffe 1991) is enshrined in the US Bill of Rights, as well as the republican commitment to civic virtue for nationhood and the separation of powers and protection against the dominance of factional interests (Dagger 2002). Despite the founding and on-going importance of the liberal concepts of liberty, rights (with the US Bill of Rights ratified in 1791) and egalitarianism and the republican concepts of citizen virtue, a system of checks and balances and political participation for public good in American political thought and nationhood construction, America's civic laws 'have often been starkly illiberal, riddled with racial, sexual, ideological, ethnic, and xenophobic discriminations' (Smith 1989, 229). Still, movements and communities, such as the US Civil Rights movement, have fought fiercely against such discriminations, arguing for racial and ethnic equality as well as the right to inclusive participation regardless of race, language, gender and sexual orientation in all areas of American society (MacLean 2010).

Australia as a nation was built on a perception of the continent as empty (Terra Nullius) denying Aboriginal Australian occupancy and sovereignty. A collective pioneering spirit was praised as opposed to individualism prioritised in the United States (Wanna 2008). The dominant discourses of Australian nation-building were socialism (through attention to social justice and workers' rights) and social-liberalism (state power with liberty for the majority) (Marsh 2008), perhaps reflecting two distinct groups of colonisers: convicts and free settlers. The class distinctive political agendas of Australia's beginnings have not continued to hold sole relevance and influence today, as Australian society has become more differentiated 'ethnically, economically and in citizen aspirations' (Marsh 2008, 148). However, the general belief in the socialist principles of 'fair go' and resentment of 'tall poppies' continue as resonant themes in Australian citizenship (Dryzek 1994).

For New Zealand, the early settler nation-building was framed in contrast to the Australian convict context, as the 'colonising crusaders' sought to compete with other potential countries for the desired, financially well-off British migrants and focused on the motifs of 'progress', 'paradise' and 'Britishness' (Belich 1996, 287), to create the 'Britain of the South' (Sinclair 1986, 16). Subsequently, New Zealand prided itself on its progressiveness and egalitarianism (social-liberalism), with frequent reference made to being the first nation to give women the vote, to harmonious race relations, and to having a social-welfare system that provided for its citizens 'from the cradle to the grave'. These motifs could and should also be questioned as myths, yet their power even as myths has had significant influence in shaping each nation. Furthermore, in New Zealand, on-going Māori activism for promised self-determination has shaped the nation's identity in distinctive ways (Walker 2004).

All three nations have progressed through their nation-building years to build increasingly diverse population bases through waves of immigration from varying 
countries of origin (Forrest and Dunn 2006), building multicultural identities to citizenship (Fozdar and Spittles 2010; Spoonley 2017). The response to multiculturalism in the United States has a historical legacy in an assumption of a 'melting pot' in which practices of differing cultural groups vanish as they merge with the larger culture, in tension with the American Mosaic approach of celebrating diverse cultural heritages (following the Civil Rights movement of the 1960s) (Owen 2005). From the 1980s, a global outlook to citizenship and democratic civic participation has been advocated in Australia (e.g. see Castles et al. [1988]); although generally there is support for multiculturalism, increasing cultural diversity has also been met with fear, suspicion of the unfamiliar and leaders feeling less certain of speaking for all Australians (Moran 2005). In New Zealand, the historical recognition of Indigenous rights of Māori and consequent 'biculturalism' has been juxtaposed with a major increase in ethnic diversity emanating from changes to immigration policy in the 1980s that resulted in the current situation of superdiversity (Royal Society of New Zealand 2013). This 'significantly enhanced diversity has altered debates about identity, nationalism and citizenship' (Spoonley 2017, 209).

The above overview provides a broad brush of some dominant ideas shaping the construction of citizenship membership and citizenship in each nation. Variously nuanced combinations of the discourses of liberalism, republicanism, social-liberalism, neo-liberalism, neo-conservatism and multiculturalism may prevail more so than others. At different epochs, discourses of citizenship are in a constant struggle to fix meaning(s) of what citizenship is and can be (e.g. see Pashby, Ingram, and Joshee [2014]). Further, these schools of thought are Western constructs, largely silencing Indigenous and other marginalised ontologies.

\section{Discourses of children and childhood in Australia, New Zealand and the United States}

The construction of child and childhood in public imaginaries is 'a deeply ambivalent attempt to harness, capture and control the movements of the future and the meanings of life-itself (Sheldon 2010, iv). Discourses regarding children define, inhibit and exclude children in citizenship theory, policy and practices. In Western societies, social policy on, for or about children typically focuses on protection (Wyness 2000) with children typically seen to belong to the "private" worlds of play, domesticity and school' (Roche 1999, 479), whereas adults generally have full access to all domains of society. Further, different socio-cultural histories inform and shape discourses of children and childhood. Childhood is read as a life stage dedicated to the indoctrination of socio-specific citizenship (see McGillivray [1997]). We look to the specific sociocultural histories in the creation of the colonised nations (Australia, New Zealand and the United States), noting influential national tropes and discourses that constructed meanings of children and childhood. In doing so we identify both similarities and differences within these national discourses of children and childhood. This is advisedly a very brief overview of hundreds of years of constructions of children and childhood given the lack of capacity to interrogate fully the complexity of tensions from varying cultural and social positions, but with the intention being rather to identify the tropes and discourses that linger in public imaginaries. 


\section{Colonisation}

Australia (see Roberts [1981]), New Zealand (see Walker [2004]) and the United States (see Wolfe [2006]; Stannard [1992]) formed as nations through barbaric acts of genocide, violation and theft of and from first nations peoples. Children were not immune to these violent histories. The eras of colonisation for the three countries were different. New Zealand was the last to be colonised, with Te Tiriti o Waitangi/the Treaty of Waitangi signed in 1840. By this time Britain had abolished slavery, the United States was to do so in 1865, and the transportation of convicts from Britain to Australia ended in 1868. Progressive ideas were apparent in the wording of the New Zealand Treaty of Waitangi, which affirmed that Māori were to be treated as equal citizens. This progressivism can be seen in some other aspects of New Zealand legislation, policy and practice in relation to both women and children, although the commitments to Māori contained in the treaty were largely ignored for 145 years (Walker 2004).

White colonialists positioned children as unknowing and innocent beings who should be distanced from community practices (Lomawaima and McCarty 2006). Colonisers variously positioned children as vulnerable in a wild unknown place, as exemplified in the 'lost child in the bush' trope of Australia (Taylor 2014), or the unruly 'wild colonial child' in New Zealand (Belich 1996). Impoverished, Indigenous and enslaved children were viewed by colonisers as needing harsh discipline and control, operationalised through missionary schooling and early childhood services (Lomawaima and McCarty 2006; Loos 2007; May 2001; Walker 2004). Schooling was seen as a means of containing, controlling and remediating social problems. For enslaved families in the United States, young children were often seen by white slaveowners as economic goods and sold away from their parents, even as infants (Berry 2017). Generations of first nations children in each country were forcibly removed from their families, communities and homelands to inculcate them into European culture and values as white-legislated nation-building practice intended to eliminate Indigenous culture and society (Human Rights and Equal Opportunity Commission 1997; Lomawaima and McCarty 2006; Walker 2004).

In the resounding national discourses in the forming of the United States as a nation - those of individualism and the American dream (Lynch 2016) - children have been and continue to be very much a part of the American dream and the assertion of individualism. In Australia, from the brutal colonising beginnings, the trope of 'the lost child' continues to haunt white settler anxieties of being displaced from familiar European landscapes to a remote and inhospitable land of strange creatures. The vulnerability encapsulated in 'the lost child' reflects 'the nation's underbelly of repressed guilt and anxiety related to colonial dispossession and destruction' (Veracini 2010, 175) and continues to perpetuate as a dominant discourse of childhood vulnerability in Australia, through education and social policy and practices that emphasise child safety over child participation. New Zealand's prevailing egalitarian ethos is seen in the 1877 Education Act which determined that all children should have at least an elementary education and again in the 1930s when the progressive ideas of the New Education Foundation were infused into the education system, offering a view of children as competent and capable (Campbell 1938). Colonial discourses often resulted in 
Indigenous children being denied equal recognition and treatment. Their citizenship was thus denied on two grounds, that of being both Indigenous and children.

\section{Progressivism}

A notion of child-centredness that emphasises the 'child as an independent and autonomous learner is largely posited on a philosophy of Western individualism' (Ang 2015, 146). In early childhood, the concept, informed by Froebel's German kindergartens, spread around the turn of the twentieth century with the commencement of kindergartens and nursery schools in Australia (Brennan 1998), New Zealand (May 1997) and the United States (Bloch et al. 2006). These philanthropic establishments focused on education and socialisation for young children (Press and Hayes 2001), foregrounding discourses of freedom of choice, enabling children to experience the freedom that had historically been denied to children who had been forced to work in mines and factories, or as farm-hands (Somerset 1976). From the 1970s, developmental psychology (largely informed by Piaget) sustained child-centredness and added the frame of developmental stages (Walkerdine 1984). The individualistic focus of child-centredness has continued to be especially resonant in the United States, with children's individual capacity constantly being affirmed by teachers, principals, television presenters, movie stars, pop stars and politicians chanting positive affirmation mantras (e.g. see [Katz 1993]; Bologna [2016]).

When birth rates declined from about the 1980s, Western societal perceptions of children shifted to see children more as unique and treasured individuals, especially amidst the middle and upper classes (van Krieken 1997). Following the ratification of the United Nations Convention on the Rights of the Child (UNCRC) in 1989, children's rights became increasingly influential in Australia and New Zealand, with social and education policy and systems slowly honouring children as rights holders. In Australia, however, the rights mostly recognised for children are those tied to safety and mechanisms of accountability (van Krieken 2010), so that discourses of child vulnerability continue to dominate public debate, with, for example, the rise of a risk-averse culture in recent decades significantly limiting children's independence and physical movement (O’Connor and Brown 2013; Rudner and Malone 2011). The rights of children, and their locatedness as family members, were recognised in the 1989 Children Young Persons, and Their Families Act in New Zealand, a progressive piece of legislation that introduced family group conferences following acknowledgement of Te Tiriti o Waitangi/The Treaty of Waitangi (Swain 1995). The United States, however, has not ratified the UNCRC for 'moral, legal and religious reasons', largely led by fundamentalist Christian lobbying (Milne 2013, 38-9) and right-wing conservatives (Swadener and Polakow 2011).

A children's rights frame, combined with studies in the sociology of childhood and the worldwide attention on philosophy of early childhood centres in Reggio Emilia, Italy, witnessed a significant move to acknowledge young children as competent and capable learners and agents from approximately the 1990s in early childhood education in Australia (Bowes 2007), New Zealand (Ministry of Education [1996] 2017) and the United States (New 2000). 


\section{Neoliberalism}

In tension with this liberal, rights-based positioning, a globalised neoliberal agenda has also widely infiltrated early childhood education. Through state regulations and compliance monitoring, neoliberalism emphasises standardisation and accountability (Baltodano 2012). And curriculum, broadly, 'is now viewed in terms of human capital formations, rather than as a way of developing an informed national citizenry' (Rizvi and Lingard 2011,12) with a lack of autonomy for educators, described as de-professionalisation (Sims et al. 2014). Following this neoliberal framing of curriculum, many nations have developed early childhood curricula (Sims 2017), such as the Australian, New Zealand and US curricula that this articles analyses. Previously, curriculum content was the professional judgement of early childhood teachers. Though Australian, New Zealand and US curricula writers did not intend to produce prescriptive recipes, the curricula are often used in this way, as compliance behaviour of educators increases due to accountability measures enacted through surveillance of practice by external bodies (e.g. see Sims and Waniganayake [2015]; Sims [2017]). 'Freedom of speech, once considered the bastion of education, is now positioned as one of the greatest threats to the state, resulting in increasing compliance enforcement throughout the education sector' (Sims 2017, 3). Further, more academic subjects are increasingly being introduced and assessed in the early childhood sector (Sims 2014). For example, the New Zealand early childhood framework, Te Whāriki, was critiqued for not providing sufficient guidance to address children's literacy and numeracy learning (e.g. McLachlan and Arrow [2011]). Te Whāriki (1996), originally crafted with a deeply embedded Māori worldview, 'is now operating in a context of tension between post-colonialism and neoliberalism' (Sims 2017, 5). In the United States, early childhood educators are required to teach a more culturally and linguistically diverse student population a standardised set of knowledge and skills to meet policy-maker academic achievement requirements (Brown, Weber, and Yoon 2015).

Through neoliberalist thinking, children's learning is understood as an investment in the labour market of the future (e.g. see Lightfoot-Rueda and Peach [2015]; Moss et al. [2016]), as evidenced in Australia with the conservative government's child care funding package introduced in 2018 entitled 'Jobs for Families', with access and provision of early child education and care based on parental participation in the workforce, not on children's rights to quality early childhood education and care. In neoliberalism, children are often referred to by what they will be able to provide to the nation as adult citizens (illustrated through economic investment arguments, and the measurement of performative outcomes), rather than for the contributions they can make to society as children. The positioning of children as investments increases their 'preciousness' and in turn their surveillance (Stover 2013).

These contrasting discourses of children and childhood continue in circulation and have influenced the shaping of each nation's current early childhood curricula and the embedded construction of children as citizens and opportunities for civic participation. 


\section{Australian early childhood curricula: Early Years Learning Framework for Australia}

In Australia, the first national curriculum for early years, the Early Years Learning Framework for Australia (EYLF) (Australian Government Department of Education, Employment and Workplace Relations 2009) was introduced in 2009 for children from birth to five years attending early childhood education and care services. ${ }^{1}$ In response to the OECD (OECD 2006) recommendation that Australia have a clearer vision for early childhood education and care, the then Australian Labor government sought to raise the status and standing of early childhood education (Rudd and Macklin 2007), with the vision that: 'All children have the best start in life to create a better future for themselves and for the nation' (Australian Government Department of Education, Employment and Workplace Relations 2009, 5). The framework foregrounded discourses of children as agentic and community connected rights holders (Sumsion and Barnes 2010). However, the media interpreted this approach as 'training kids to be political activists' (see Letters [2009]), reflecting public contestation of a view of children as agential for its contrast to the nationally treasured trope of the innocent and vulnerable child (Sumsion and Grieshaber [2012]).

The Framework outlines five learning outcomes whereby children: have a strong sense of identity; are connected with and contribute to their world; have a strong sense of wellbeing; are confident, involved learners; and are effective communicators. These learning outcomes are interwoven with five principles: secure, respectful and reciprocal relationships; partnerships with families; high expectations and equity; respect for diversity; on-going learning and reflective practice; and a repertoire of pedagogical practices. Ortlipp, Arthur, and Woodrow (2011) argue that the 'principles can be seen to function as discourses, constituting the beliefs, values and practices produced within them as normal, right and desirable' (63). Australia's early years learning framework foregrounds respect for diversity as a key principle and cultural competence as a key practice to attend to Australia's socially and cultural diverse society. Attention to Aboriginal Australian ways of being and knowing is disappointingly subsumed in this broader practice of cross-cultural competence. Though the writers had a participatory social justice orientation, the governmental approval process pushed toward a more moderate final version (Millei and Sumsion 2011).

\section{New Zealand early childhood curriculum: Te Whāriki}

Te Whāriki, ${ }^{2}$ He whāriki mātauranga mō ngā mokopuna o Aotearoa: Early Childhood Curriculum (New Zealand Ministry of Education [1996] 2017), the first New Zealand early childhood curriculum, was developed in the early 1990s, embracing discourses of the child as 'capable and competent' contributors to their early childhood communities and reflecting the discursive context of the time (Mutch 2004). Not only had New Zealand just signed the UN Convention on the Rights of the Child, but the year 1990 was the sesquicentennial of the signing of Te Tiriti o Waitangi/The Treaty of Waitangi, which had allowed British settlement along with recognition of Māori self-determination. Helen May (2005), one of the writers of Te Wharriki, points out that the curriculum document was both 'grounded in the rights of children' as well as acknowledging 
'the rightful place of indigenous Māori knowledge', with its 'foundation principle being the "empowerment" of children and families' (23). This discourse of empowerment seems to characterise a particularly New Zealand ethos of progressivism. The curriculum was unique in its focus on recognition of the language and values of the Indigenous Māori, on responsive and reciprocal relationships with people, places and things, on empowerment, and on fostering children's capacity to contribute to both the early childhood setting and wider community. This implicit recognition of Māori children and families as equal citizens was an enlightened recognition of their rights and status as first nation peoples. Te Whäriki was recently updated (New Zealand Ministry of Education [1996] 2017), whilst maintaining much of the intent of the original document.

The overall 'aspiration statement' of Te Whäriki is oriented towards preparing children to be contributing citizens, stating that teachers aspire for children to grow up as 'competent and confident learners and communicators, healthy in mind, body and spirit, secure in their sense of belonging and in the knowledge that they make a valued contribution to society' (New Zealand Ministry of Education [1996] 2017, 5). Te Whäriki has four overarching principles: Empowerment/Whakamana; Holistic Development/Kotahitanga; Family and Community/Whānau/Tangata; and Relationships/Ngā Hōnonga. These principles are to be interwoven with five strands: Wellbeing/Mana Atua; Belonging/Mana Whenua; Contribution/Mana Tangata; Exploration/Mana Aotūroa; and Communication/Mana Reo. Each of these strands contains a range of goals, and under each of these specific learning outcomes are illustrated. These principles and strands reflect a discourse of an empowered, agentic child embedded within and contributing to family, centre and community relationships in keeping with the wider national discourse of progressivism and democracy.

\section{US early childhood curriculum: NAEYC DAP and Head Start}

The most influential frameworks that inform practice in many of the public early childhood educational programmes in the United States are the National Association for the Education of Young Children's (NAEYC) Developmentally Appropriate Practice (DAP) Position Statement (National Association for the Education of Young Children 2009) ${ }^{3}$ and the Head Start Child Development and Early Learning Framework (US Department of Health and Human Service 2015). NAEYC is considered the premier early childhood education organisation in the United States and is often tasked with defining high-quality early childhood education. NAEYC worked tirelessly in the 1980s and 1990s to argue for play-based curriculum through the concept of 'developmentally appropriate practice'. The argument was that young children learn through play and do not benefit developmentally from learning through rote memorisation and teacherdirected work. This emphasis has not been strong enough, however, to overcome the enormous pressure to use early childhood education as academic preparation. The current DAP position statement was adopted by NAEYC in 2009 (there have been two earlier editions: 1987 and 1997) and saw a shift in foregrounding academic skill development (such as literacy and numeracy) over socio-culturally informed development, reflective of the discourse of child as human capital contributing to a nation's measurable academic outputs (see Brown, Weber, and Yoon [2015]). The document is 
organised into three key knowledge areas for teachers: knowledge to consider in making decisions (three areas); principles of child development and learning that inform practice (12 principles); and guidelines for developmentally appropriate practice (five key areas).

The Head Start Program commenced in 1965 (Krogh and Slentz 2010) funded by the federal government and aimed at economically disadvantaged children. Originally the Head Start Child Development and Early Learning Framework (US Department of Health and Human Services 2010) was meant to ensure high-quality learning environments for young children in the Head Start programme. This framework was revised in 2015 as the Head Start Early Learning Outcomes Framework (US Department of Health and Human Services 2015) to also focus on subject matter to align more closely with school curricula in support of school preparation. It contains 11 domains, each of which centres on an area of child development that is considered 'essential for school and long-term success' (US Department of Health and Human Services 2015, 1). These domains are structured into 37 domain elements that are designed to guide teachers' assessment efforts and ideas about curriculum. The document is quick to point out that children have varying ways of (and age-based stages) demonstrating competency in different domains. All Head Start programmes are mandated to use the framework to plan and structure teaching and learning activities as well as the environment.

Both US frameworks give some attention to the cultural and linguistic identities of young children (though no specific attention to Indigeneity), through attention to honouring the home languages and cultures of children and families and linguistic development in home languages whenever possible. However, there is no mention of children's rights in either document; instead, individual learning and demonstration of knowledge and skills is prioritised.

Different discourses, national contexts and agendas have produced very different early childhood curricula in each nation, even illustrative in the document titles. We will now locate examples from within each nation's curricula analysing how children are defined as citizens and the potential opportunities for citizenship participation.

\section{Young children's citizenship membership and participation reflected in early years curricula}

To understand how children are positioned as citizens and what opportunities there are for citizenship participation in the three nations' early years curricula, we read the curricula documents for illustrative content that reflected key signifiers of citizenship membership and participation. We each assessed our respective nation's documents to locate references to what might be connected to these citizenship components (see Tables 1 and 2). We shared these lists with one another and deliberated on the meaning of each concept until we reached consensus on key signifiers informed by citizenship literature and which could be applied to early childhood education. Once we had located examples with signifiers of each concept in the four curricula documents, we conducted close readings to investigate the ways in which discourses of children as citizens, and early childhood settings as social spaces for citizenship participation, are organised discursively. The meaning of each signifier was determined by its relation to other signs, what Jorgensen and Phillips (2002) refer to as chains of equivalence. Terms 
Table 1. Curricula excerpts that reflect membership for young children.

Early Years Learning Framework for Australia

'Children belong first to a family, a cultural group, a neighbourhood and a wider community. Belonging acknowledges children's interdependence with others and the basis of relationships in defining identities' (Vision for children's learning, 7)

'Children are connected with and contribute to their world' (Outcome 2, 25)

'Children develop a sense of belonging to groups and communities and an understanding of the reciprocal rights and responsibilities necessary for active community participation' (Outcome 2 point 1, 26)

Te Whāriki (Aotearoa/New Zealand) ${ }^{4}$

'Children and their families experience an environment where: connecting links with the family and the wider world are affirmed and extended; they know that they have a place' (Belonging, 32)

'Kaiako [teachers] are cognisant of the concept of tangata whenua [Indigenous people] and the relationship that Māori have to each other and to the land. This guides kaiako relationships with whānau [extended families], hapū [sub-tribes] and iwi [tribes]. Kaiako share appropriate histories, kōrero [stories] and waiata [songs] with mokopuna [children] to enhance their identity and sense of belonging' (Belonging, 33)

'The interdependence of children, whānau and community is recognised and supported' (Belonging, 35)

NAEYC Developmentally Appropriate Practice position statement (United States)

'Teachers bring each child's home culture and language into the shared culture of the learning community so that the unique contributions of that home culture and language can be recognized and valued by the other community members, and the child's connection with family and home is supported' (Key area of practice 2. Teaching to enhance development and learning, 20)

Head Start Early Learning Outcomes Framework (United States)

'Child has a sense of belonging to family, community and communicates details about these connections' (4860 months Goal P-SE 11, 33)

'Identifies self as being a part of different groups, such as family, community, culture, faith, or preschool' (By 60 months Goal P-SE 11, 33)

Table 2. Curricula excerpts that reflect citizenship participation education for young children.

Early Years Learning Framework for Australia

'Children are connected with and contribute to their world' (Outcome 2, 25)

'Children develop a sense of belonging to groups and communities and an understanding of the reciprocal rights and responsibilities necessary for active community participation ... children take action to assist other children to participate in social groups ...

'Educators promote this learning when they

* build connections between the early childhood setting and the local community

* provide opportunities for children to investigate ideas, complex concepts and ethical issues that are relevant to their lives and their local communities' (Outcome 2, Point 1, 26)

Te Whāriki (Aotearoa/New Zealand)

'A fundamental expectation is that each service will offer a curriculum that recognises these rights and enables the active participation of all children, including those who may need additional learning support' (12)

'An ability to connect their learning in the ECE setting with experiences at home and in familiar cultural communities and a sense of themselves as global citizens' (32)

'Working together for the common good develops a spirit of sharing, togetherness and reciprocity, which is valued by Pasifika and many other cultures' (Contribution, 36)

'Social skills and the ability to take responsibility for fairness in their interactions with others' (Contribution, 37)

'Strategies for resolving conflicts in peaceful ways and an awareness of cultural values and expectations' (Contribution, 37)

'A sense of responsibility and respect for the needs and wellbeing of the group, including the ability to take responsibility for group decisions' (Contribution, 37)

'Confidence to stand up for themselves and others against biased ideas and discriminatory behaviour' (Contribution, 37)

NAEYC DAP position statement (USA)

Point 2 - cooperates with others

Point 5 - uses social appropriate behavior with peers and adults, such as sharing, helping and taking turns (20)

Head Start Early Learning Outcomes Framework (USA)

'Young children engage in positive interactions with adults in a variety of situations, including everyday routines' (Goal IT-SE4, 25)

'Shows ongoing connection to a conversation, group discussion, or presentation' (Goal P-LC1, 42) 
such as 'children' and 'participation' were understood as floating signifiers as varying discourses competed to ascribe the term with meaning. Readings of chains of equivalence identified patterns reflecting hegemonic discourses of children, childhood and citizenship and how they shape the language and intent of the curricula documents. This discourse analysis sought to enhance understanding of how children's potential for citizenship participation with(in) communities may or may not be supported by early childhood curricula documents.

Citizenship membership and participation are examined one by one as a systematic means to organise communication of the analysis. However, they are not distinctly separate, so some illustrative examples can be read to reflect both identity and participation. First, a brief definition of the citizenship component is provided, followed by a table of illustrative curricula content (key signifiers indicated in bold), then comparative discourse analysis.

\section{Citizenship membership}

'Membership lies at the heart of citizenship. To be a citizen is to belong to a given political community' (Bellamy 2008, 53). As noted earlier, we recognise early childhood settings as often the first political community for young children. We are interested to see how citizenship membership is defined in the three curricula, to see how children are positioned as citizens, that is, what the scope for their inclusion as contributing citizens is. Membership is not explicitly named in any of the curricula documents, so key associated signifiers identified included: belong/ing; interdependence; member; relationships; identify; identity; and references to groups children will belong to, such as families, communities, culture and language. The relationship communicated between these signifiers and the floating signifier of 'children' identified chains of equivalence from which readings of discourses of children, childhood and citizenship could be inferred.

Construction of children's membership as belonging and connected to family, groups, neighbourhoods and the wider community are key themes of the EYLF, Te Whäriki and Head Start Early Learning Outcomes Framework. Such a conception of belonging implies emotional attachment to various groupings and collectivities (reflecting a more protected view of childhood), whilst the ethical and political facets of belonging are not foregrounded (Yuval-Davis 2011). Scope of allegiances are acknowledged, although neither their specificity nor children's subject positions, when attention to membership is broadly defined as belonging to families and communities. Interestingly, the overarching political act of constructing Te Whäriki as a bilingual/ bicultural document profoundly honours young Māori children's cultural and linguistic membership, reflecting the discourse of a Māori child as a whānau participant in expressions of rangatiratanga (Māori self-determination). Further, Te Whāriki acknowledges the sense of belonging that is intrinsic to Māori identification with the land.

In the EYLF and in Te Whäriki, children's citizenship membership is presented as interdependent, acknowledging the interconnectedness of children within society seeing them as valued contributors with adults reliant on them as much as children are reliant on adults. The use of the word interdependent shifts away from hierarchical 
perceptions of adult-child relations to generate equal reciprocal relations, reflecting the social justice and egalitarian foundations of Australian and New Zealand citizenship. Explicit reference to children's rights to active community participation and understanding reciprocal rights and responsibilities in the EYLF further qualifies the scope of children's citizenship membership, - that it is not just about belonging, but also about inclusion in active citizenship participation, illustrative of how the framework foregrounds children as agentic and community connected rights holders (Sumsion and Barnes 2010).

Children's membership of cultural and linguistic groups is a key focus in the NAEYC DAP Position Statement and Head Start Early Learning Outcomes Framework, acknowledging specific allegiances to children's home cultures and languages. The honouring of culture and language membership is an important component of US early years curricula documents, echoing the legacy of the US Civil Rights movement (Goldenberg and Wagner 2015) and mosaic approach to multicultural citizenship (Owen 2005). Specific focus on language and culture may, however, deflect attention away from many other (perhaps more political) membership elements, such as Indigeneity, ability, sexuality, faith and class. Construction of children's memberships with allegiances to broader social collectivities, such as neighbourhoods and society, are absent in the NAEYC DAP statement, suggestive of a more protective view of childhood and perhaps a greater focus on the individual than the collective.

\section{Citizenship participation}

Citizenship participation in democratic societies is the enactment of ruling, by participating in societal decision-making, and enacting rights and responsibilities as citizens (Bellamy 2008; Hart, Richardson, and Wilkenfeld 2011). We look to early childhood curricula to see what opportunities there are for young children's citizenship participation, that is, to see what the defined scope is for their participation as citizens. Key signifiers that were read to define young children's participation included: contribute; active community participation; responsibility; taking turns; problem-solving; negotiating; resolving conflicts; stand-up; co-operate; sharing; and helping. Other bolded words reflect the context of the citizenship participation, such as groups and local communities and others.

Young children's participation is defined in local communities in the EYLF, though confined to 'their world' reflecting a pedagogical pattern of reducing demand for the young, attentive to prevalent discourses of children as innocent and vulnerable. As MacNaughton, Hughes and Smith (2007) noted, a major limitation for children's participation in early childhood is that educators are positioned as experts in child development, thus determining what is appropriate without consultation with children. A more comprehensive definition of participation is offered with the requirement of an 'understanding of the reciprocal rights and responsibilities', acknowledging the scope of political citizenship as rights and responsibilities of the communities of which children are members. Further, reciprocity of rights and responsibilities is acknowledged, so that children are understood to have citizenship rights and responsibilities and they are to understand others have rights and responsibilities too. The practices suggested for children's citizenship participation (e.g. to investigate ideas, complex concepts and 
ethical issues relevant to their lives and communities) indicate discourses of children as rights holders and claimers, and define citizenship participation for young children as that which is community oriented and relevant to children's lives. Children, like adults, are more likely to invest in matters that are relatable, through shared identity/membership/belonging (Bellamy 2008).

Te Whäriki describes citizenship participation as inclusive for all children regardless of ability, offering an inclusive approach to citizenship attending to political belonging (Yuval-Davis 2011) and reflecting New Zealand's progressivist origins and prevailing egalitarian ethos. Attention to fairness, peace-building, bias and discrimination, inspired by the anti-bias curriculum (Derman-Sparks 1989), reflects childhood discourses of children as rights holders and citizenship discourses of progressivism and egalitarianism prevalent in New Zealand - as well as Māori values such as kotahitanga (unity, solidarity) and mana (prestige) which support community participatory skill development from a young age. Support for children's politically inclusive grouporiented citizenship participation is strong throughout Te Whäriki, representative of contemporary discourses for diversity and children as active contributors.

The closest illustrative example of citizenship participation in the NAEYC DAP is the reference of 'cooperates with others', suggestive of controlled childhoods and neoliberal compliance. There is no indication of the scope or context for cooperation, and there is no suggestion of actions for community. Likewise, in the Head Start Early Learning Outcomes Framework, there is only a reference to interactions with adults and connection to group conversations, also indicative of emphasis on compliance as essential for the learning process. Hegemonic discourses of education as a means to remediate socialisation of children persist, along with neoliberalist discourses foregrounding compliance of performative outcomes.

\section{Closing discussion}

The curricular analysis presented here identifies how children are constructed as citizens in Australian, New Zealand and US early childhood curricula, along with how opportunities for young children's citizenship participation are defined. Prevalent national discourses of citizenship and children and childhood are traceable in the illustrative curricula examples. In the Australian curriculum, the recent influence of discourses of children as social actors and rights holders dominated (largely made possible as the writers held such views of children); however, as Laclau and Mouffe note, there are constant discursive struggles, and in the Australian illustrative examples, the trope of the innocent and vulnerable child lingers by softening or narrowing the scope of citizenship participation for young children to 'their world'. In New Zealand, discourses of children as social actors and rights holders were also foregrounded, along with politically inclusive discourses and Māori child as a whānau participant in expressions of rangatiratanga (self-determination) reflecting the bicultural and political agenda of the forming of Te Whäriki. In contrast, discourses of controlled childhoods continue to dominate meanings ascribed to young children as citizens and citizenship participation in the US early childhood curricula documents, with some traces of mosaic approaches to citizenship celebrating cultural diversity asserting cultural membership. The scope for children's identity and participation are narrowed to the early 
childhood setting and compliance. There is no mention of children participating in the wider community, continuing American citizenship themes of individualism merged with a neoliberal ideology of compliance.

From this analysis, it can be read that discursive conditions in support of children as citizens who can actively participate are more present in Australia and New Zealand than in the United States. It is also important to note that New Zealand has by far the smallest population with a unitary, as opposed to a federal, political system and thereby it is much easier to move critical mass for social change for support for active participation for political issues of fairness, peace-building, bias and discrimination. The affirmation in Te Tiriti o Waitangi/the Treaty of Waitangi of Māori rangatiranga, or self-determination, over elements of value such as land and language is a discourse reflecting the comparatively later, more progressive era of initial colonisation of New Zealand, and is reflected in the discourse of empowerment and inclusion of Māori evident in Te Whäriki (Walker 2004). The fact that the Te Whäriki is bilingual and bicultural suggests that the discursive conditions that are supportive of Indigenous rights are also more supportive of young children's rights to be recognised as active participants in broader society.

It is also important to note that the discursive field is not simple or fixed; discourses continue to be in flux. The persistent influence of discourses, such as that of the innocent and unknowing child, act to regulate children's access to knowledge and experience (Robinson 2013). We recognise that children are the most subjugated group in humanity (Perez 2013), and continue to experience horrendous human rights abuses; however, we see focus on children's vulnerability often working to take away children's agency and rights. Through education that acknowledges children's citizenship membership and participation, children become informed and skilled to collaborate and negotiate challenges with others. If societies and education settings fail to affirm children as active contributors to society, who are responsible for self and others, including the environment, and who can respond to and negotiate multiple perspectives and participate in school and community decision-making and actions, then education perpetuates the construction of children as unknowing and vulnerable.

We argue that curricula that explicitly position children and young people as agential (as opposed to passive compliant subjects) will produce greater intergenerational civic engagement supportive of social understanding and cohesion. And it is through intergenerational collaboration that honours children as citizens, as well as becomings (just as we all are regardless of age), that collective civic learning occurs. We advocate for creating more informed young citizens through viewing civic learning as a life-long continuum. By no means are we suggesting this to be a simplistic solution to complex social and environmental problems. For each child, in each education setting, in each community, in each jurisdiction, in each nation there are complexities, requiring responsive caring communities who welcome children as political agents and continuously co-negotiate the politics of co-existence.

\section{Notes}

1. Education in Australia is a state and territory responsibility, so some states have adapted the EYLF to create a state early childhood curriculum. EYLF is the nationally approved 
educational programme for registered education and care services for birth to five-yearolds to utilise.

2. Te Whāriki literally means the woven flax mat. It is a metaphor for weaving the curriculum principles and strands together to form a curriculum particular to each setting. Te Whäriki is the mandated curriculum for all licensed early childhood care and education services in New Zealand. These services include kindergarten, Playcentre, Kōhanga Reo and other early education and care settings.

3. The NAEYC Developmentally Appropriate Practice (DAP) Position Statement provides guidelines by which childcare programmes can be accredited in the United States. Accreditation is not mandated, though NAEYC accreditation is a nationally recognised symbol of quality early learning programmes.

4. Please note we have used selected examples only in each of the Aotearoa sections.

\section{Acknowledgements}

The authors greatly appreciate the thoughtful feedback provided on earlier versions of this article by Bob Lingard, Christine Winter and Andrew Peterson, along with the provocations from anonymous reviewers - all of which assisted in the formation of this work.

\section{Disclosure statement}

No potential conflict of interest was reported by the authors.

\section{Funding}

This work was supported by the Spencer Foundation's New Civics Initiative under Grant number 201400172.

\section{ORCID}

Louise Gwenneth Phillips (D) http://orcid.org/0000-0002-2937-145X

Jenny Ritchie (D) http://orcid.org/0000-0003-2934-6358

\section{References}

Adair, J. K., L. G. Phillips, J. Ritchie, and S. Sachdeva. 2017. "Civic Action and Play: Examples from Maori, Aboriginal Australian and Latino Communities." Early Child Development and Care 187 (5-6): 798-811. doi:10.1080/03004430.2016.1237049.

Alcock, S., and M. Haggerty. 2013. "Recent Policy Developments and the "Schoolification" of Early Childhood Care and Education in Aotearoa New Zealand." Early Childhood Folio 17 (2): $21-26$.

Anckar, C. 2008. "On the Applicability of the Most Similar Systems Design and the Most Different Systems Design in Comparative Research." International Journal of Social Research Methodology 11 (5): 389-401. doi:10.1080/13645570701401552.

Ang, L. 2015. "Rethinking Child-Centred Education." In The Sage Handbook of Curriculum Pedagogy and Assessment, edited by D. Wyse, L. Hayward, and J. Pandya, 141-152. Thousand Oaks, CA: Sage.

Australian Government Department of Education, Employment and Workplace Relations. 2009. Belonging, Being and Becoming: The Early Years Learning Framework for Australia. Canberra: Australian Government Department of Education. 
Baltodano, M. 2012. "Neoliberalism and the Demise of Public Education: The Corporatization of Schools of Education." International Journal of Qualitative Studies in Education 25: 14871507. doi:10.1080/09518398.2012.673025.

Belich, J. 1996. Making Peoples. A History of the New Zealanders from Polynesian Settlement to the End of the Nineteenth Century. Auckland: Penguin.

Bellamy, R. 2008. Citizenship: A Very Short Introduction. Oxford: Oxford University Press.

Berry, D. R. 2017. The Price for Their Pound of Flesh: The Value of the Enslaved, from Womb to Grave, in the Building of a Nation. Boston, MA: Beacon Press.

Bloch, M., D. Kennedy, T. Lightfoot, and D. Weyenberg, eds. 2006. The Child in the World/The World in the Child: Education and the Configuration of a Universal, Modern, and Globalized Childhood. Dordrecht: Springer.

Bologna, C. 2016. "Teacher's Inspiring Mantra for Students Will Reaffirm Your Hope for the Future." Huffington Post, November 11. http://www.huffingtonpost.co.uk/entry/teachers-inspir ing-mantra-for-students-will-reaffirm-your-hope-for-the-future_us $5829 \mathrm{cf} 29 \mathrm{e} 4 \mathrm{~b} 060 \mathrm{adb} 56 \mathrm{f} 3 \mathrm{de} 5$

Bowes, J. 2007. “Australia: Pedagogies in Early Childhood Education.” In Early Childhood Education International Encyclopaedia, edited by R. New and C. Mocrieff, 883-887. Vol. 4. Westport, CT: Greenwood Publishing.

Brennan, D. 1998. The Politics of Australian Child Care: Philanthropy to Feminism and Beyond. Rev. ed. Cambridge: Cambridge University Press.

Brown, C. P., N. Weber, and Y. C. Yoon. 2015. “The Practical Difficulties for Early Educators Who Tried to Address Children's Realities in Their High-Stakes Teaching Context.” Journal of Early Childhood Teacher Education 36 (1): 3-23. doi:10.1080/10901027.2014.996925.

Campbell, A. E., ed. 1938. Modern Trends in Education: The Proceedings of the New Education Fellowship Conference Held in July, 1937. Wellington: Whitcombe and Tombs.

Castles, S., M. Kalantzis, B. Cope, and M. Morrissey. 1988. Mistaken Identity: Muticulturalism and the Demise of Nationalism in Australia. Sydney: Pluto Press.

Chartier, A.-M., and N. Geneix. 2006. "Pedagogical approaches to early childhood education." Background paper prepared for the EFA Global Monitoring Report 2007, Strong foundations: early childhood care and education. http://unesdoc.unesco.org/images/0014/001474/147448e.pdf Corsaro, W. 2005. The Sociology of Childhood. 2nd ed. Thousand Oaks, CA: Pine Forge Press.

Dagger, R. 2002. "Republican Citizenship." In Handbook of Citizenship Studies, edited by E. F. Isin and B. S. Turner, 145-157. London: Sage Publications.

Davis, J. M. 2010. "What Is Early Childhood Education for Sustainability?" In Young Children and the Environment: Early Education for Sustainability, edited by J. M. Davis, 7-31. Cambridge Books Online: Cambridge University Press.

Derman-Sparks, L. and the A.B.C. Task Force. 1989. Anti-Bias Curriculum. Tools for Empowering Young Children. Washington, DC: National Association for the Education of Young Children.

Dryzek, J. S. 1994. "Australian Discourses of Democracy.” Australian Journal of Political Science 29 (2): 221-239. doi:10.1080/00323269408402291.

Flanagan, C. 2012. Civic Learning/Civic Action: The State of the Field. Commissioned Report for the Spencer Foundation's Strategic Initiative on Civic Learning and Civic Action. Chicago, IL: Spencer Foundation.

Forrest, J., and K. Dunn. 2006. "'Core' Cultural Hegemony and Multiculturalism: Perceptions of the Privileged Positions of Australians with British Backgrounds." Ethnicities 6 (2): 203-230. doi:10.1177/1468796806063753.

Fozdar, F., and B. Spittles. 2010. "Patriotic Vs Proceduralist Citizenship: Australian Representations." Nations and Nationalism 16 (1): 127-147.

Gibson, A. 2000. "Ancients, Moderns and Americans: The Republicanism-Liberalism Debate Revisited." History of Political Thought 21 (2): 261-307.

Goldenberg, C., and C. Wagner 2015. Bilingual Education: Reviving and American Tradition. American Educator. Fall issue. https://www.aft.org/ae/fall2015/goldenberg_wagner 
Hart, D., C. Richardson, and B. Wilkenfeld. 2011. "Civic Identity." In Handbook of Idenity Theory and Research, edited by S. J. Schwartz, K. Luyckx, and V. L. Vignoles, 771-787. New York: Springer.

Heater, D. 1999. What Is Citizenship. Cambridge: Polity Press.

Howe, R. B., and K. Covell. 2005. Empowering Children: Children?S Rights Education as a Pathway to Citizenship. Toronto: University of Toronto Press.

Hughes, A. S., M. Print, and A. Sears. 2010. "Curriculum Capacity and Citizenship Education: A Comparative Analysis of Four Democracies." Compare: A Journal of Comparative and International Education 40 (3): 293-309. doi:10.1080/03057920903395528.

Human Rights and Equal Opportunity Commission. 1997. Bringing Them Home: National Inquiry into the Separation of Aboriginal and Torres Strait Islander Children from Their Families. Sydney: Human Rights and Equal Opportunity Commission.

James, A., C. Jencks, and A. Prout. 1998. Theorizing Childhood. Oxford: Polity Press.

Jerome, L. 2017. "What Do Citizens Need to Know? an Analysis of Knowledge in Citizenship Curricula in the UK and Ireland." Compare: A Journal of Comparative and International Education 1-17. doi:10.1080/03057925.2017.1295808.

Jorgensen, M., and L. Phillips. 2002. Discourse Analysis as Theory and Method. London: Sage.

Katz, L. 1993. "From Our President. Are We Confusing Self-Esteem and Narcissism?" Young Children 49 (1): 2-3.

Kessler, S. A., and B. B. Swadener, eds. 1992. Reconceptualizing the Early Childhood Curriculum: Beginning the Dialogue. New York: Teachers College Press.

Krogh, S., and K. Slentz. 2010. Early Education: Yesterday, Today and Tomorrow. New York: Routledge.

Kymlicka, W. 2001. Politics in the Vernacular: Nationalism, Multiculturalism, and Citizenship. Oxford: Oxford University Press.

Laclau, E., and C. Mouffe. 1985. Hegemony and Socialist Strategy: Towards a Radical Democratic Politics. London: Verso.

Lansdown, G. 2005. Innocenti Insight: The Evolving Capacities of the Child. Florence: UNICEF Innocenti Research Centre.

Letters. 2009. Young Activists. Adelaide Advertiser, April 17. Florence: UNICEF Innocenti Research Centre.

Lightfoot-Rueda, T., and R. L. Peach. 2015. "Introduction and Historical Perspective." In Global Perspectives on Human Capital in Early Childhood Education: Reconceptualizing Theory, Policy, and Practice, edited by T. Lightfoot-Rueda and R. L. Peach, 3-25. New York: Palgrave Macmillan.

Lomawaima, K. T., and T. L. McCarty. 2006. To Remain an Indian: Lessons in Democracy from a Century of Native American Education. New York: Teachers College Press.

Loos, N. 2007. White Christ: Black Cross. Canberra: Aboriginal Studies Press.

Lynch, M. 2016. "3 Important Themes of American Culture that Influence Our Schools." The Advocate, September 19. http://www.theedadvocate.org/3-important-themes-of-american-cul ture-that-influence-our-schools/

MacLean, N. 2010. “The Civil Rights Movement: 1968-2008.” Freedom’s Story, TeacherServe. National Humanities Center. http://nationalhumanitiescenter.org/tserve/freedom/ 1917beyond/essays/crm2008.htm

MacLure, M. 2003. Discourse in Educational and Social Research. Buckingham: Open University Press.

MacNaughton, G. 2007. Trials and Transitions to Citizenship: What Really Matters in Early Childhood Education?. Dean's Lecture Series. Faculty of Education, University of Melbourne.

MacNaughton, G., P. Hughes, and K. Smith. 2007. "Young Children's Rights and Public Policy: Practices and Possibilities for Citizenship in the Early Years." Children \& Society 21 (6): 458-469.

MacNaughton, G., P. Hughes, and K. Smith, eds. 2008. Young Children as Active Citizens: Principles, Policies and Pedagogies. Newcastle, UK: Cambridge Scholars Publishing. 
Marsh, I. 2008. "Re-Imagining the Australian State: Political Structures and Policy Strategies." In Australia under Construction: Nation-Building Past, Present and Future, edited by J. Butcher, 147-171. Canberra: ANU Press.

May, H. 1997. The Discovery of Early Childhood. Auckland: Bridget Williams Books, Auckland University Press.

May, H. 2001. "Mapping Some Landscapes of Colonial-global Childhood Ece@2000.europe. antipodes." European Early Childhood Education Research Journal 9 (2): 5-20. doi: 10.1080/ 13502930185208731.

May, H. 2005. "A 'Right as Citizen to A Free [Early Childhood] Education.' 1930s-2000s." Childrenz Issues 9 (2): 20-49.

McGillivray, A. 1997. Governing Childhood. Aldershot: Dartmouth Publishing Company.

McLachlan, C., and A. Arrow. 2011. "Literacy in the Early Years in New Zealand: Policies, Politics and Pressing Reasons for Change." Literacy 45: 126-133. doi:10.1111/j.17414369.2011.00598.x.

Millei, Z., and J. Sumsion. 2011. “The 'Work' of Community in Belonging, Being and Becoming: The Early Years Learning Framework for Australia." Contemporary Issues in Early Childhood 12 (1): 71-85.

Milne, B. 2013. The History and Theory of Children's Citizenship in Contemporary Societies. Dordrecht: Springer.

Moran, A. 2005. Australia: Nation, Belonging and Globalization. New York: Routledge.

Moss, P., G. Dahlberg, S. Grieshaber, S. Mantovani, H. May, A. Pence, M. Vandenbroeck, B. B. Swadener, and M. Vandenbroeck. 2016. "The Organisation for Economic Co-Operation and Development's International Early Learning Study: Opening for Debate and Contestation.” Contemporary Issues in Early Childhood 17: 343-351. doi:10.1177/1463949116661126.

Mouffe, C. 1991. "Democratic Citizenship and the Political Community." In Community at Loose Ends, edited by Miami Theory Collective, 70-82. Minneapolis, MN: Minnesota Press.

Mutch, C. 2004. "Educational Policy and Notions of Citizenship in Four Asia-Pacific Societies." Asia Pacific Education Review 5 (2): 178-187. doi:10.1007/BF03024955.

National Association for the Education of Young Children. 2009. Developmentally Appropriate Practice in Early Childhood Programs Serving Children from Birth through Age 8: A Position Statement of the National Association for the Education of Young Children. Washington, DC: National Association for the Education of Young Children.

New, R. 2000. "The Reggio Emilia Approach: It's Not an Approach-It's an Attitude." In Approaches to Early Childhood Education, edited by J. Roopnarine and J. Johnson, 341-358. Columbus, OH: Merrill.

New Zealand Ministry of Education. [1996] 2017. Te Whāriki. He Whāriki Mātauranga mō ngā Mokopuna o Aotearoa: Early Childhood Curriculum. Wellington: Learning Media.

O'Connor, J., and A. Brown. 2013. "A Qualitative Study of 'Fear' as A Regulator of Children's Independent Physical Activity in the Suburbs.” Health and Place 24: 157-164. doi:10.1016/j. healthplace.2013.09.002.

Organisation for Economic Co-operation and Development (OECD). 2006. Starting Strong II: Early Childhood Education and Care. Paris: OECD.

Ortlipp, M., L. Arthur, and C. Woodrow. 2011. "Discourses of the Early Years Learning Framework: Constructing the Early Childhood Professional." Contemporary Issues in Early Childhood 12 (1): 56-70. doi:10.2304/ciec.2011.12.1.56.

Owen, D. 2005. "American Identity, Citizenship, and Multiculturalism." Paper presented at German-American Conference cosponsored by the Bundeszenrale fur politische Bildung and the Center for Civic Education, Freiburg, Germany, September 11-16. http://www.civiced.org/ pdfs/germanPaper0905/DianaOwen2005.pdf

Pashby, K., L.-A. Ingram, and R. Joshee. 2014. "Discovering, Recovering, and Covering-Up Canada: Tracing Historical Citizenship Discourses in K-12 and Adult Immigrant Citizenship Education." Canadian Journal of Education 37 (2): 1-26.

Perez, M. 2013. "Complicating 'Victim' Narratives: Childhood Agency Within Violent Circumstances." Global Studies of Childhood 4 (2): 126-134. 
Peterson, A. 2011. Civic Republicanism and Civic Education: The Education of Citizens. Basingstoke: Palgrave MacMillan.

Phillips, L. G. 2011. "Possibilities and Quandaries for Young Children's Active Citizenship." Early Education and Development 22 (5): 778-794. doi:10.1080/10409289.2011.597375.

Press, F., and A. Hayes. 2001. OECD Thematic Review of Early Childhood Education and Care Policy: Australian Background Report. Sydney: Institute of Early Childhood, Macquarie University.

Rizvi, F., and B. Lingard. 2011. "Social Equity and the Assemblage of Values in Australian Higher Education." Cambridge Journal of Education 41: 5-22. doi:10.1080/ $0305764 X .2010 .549459$.

Roberts, J. 1981. Massacres to Mining: The Colonisation of Aboriginal Australia. Melbourne: Dove Communications.

Robinson, K. H. 2013. Innocence, Knowledge and the Construction of Childhood: The Contradictory Nature of Sexuality and Censorship in Children's Contemporary Lives. Abingdon: Routledge.

Roche, J. 1999. "Children: Rights, Participation and Citizenship." Childhood 6 (4): 475-493. doi:10.1177/0907568299006004006.

Rosenof, T. 2010. “The Propensity to Reform: The United States, Australia, New Zealand and Canada Compares.” The Historian 72 (1): 38-66. doi:10.1111/j.1540-6563.2009.00256.x.

Royal Society of New Zealand. 2013. Languages in Aotearoa New Zealand. https://royalsociety. org.nz/what-we-do/our-expert-advice/all-expert-advice-papers/languages-in-aotearoa-newzealand/

Rudd, K., and J. Macklin. 2007. "New Directions for Early Childhood Education: Universal access to early learning for 4 year olds." Australian Labor Party. http://parlinfo.aph.gov.au/parlInfo/ download/library/partypol/JRPO6/upload_binary/jrpo63.pdf;fileType=application/pdf.

Rudner, J., and K. Malone. 2011. "Childhood in the Suburbs and the Australian Dream: How Has It Impacted Children's Independent Mobility?” Global Studies of Childhood 1 (3): 207-225. doi:10.2304/gsch.2011.1.3.207.

Sawer, M., K. McLaren, and N. Kelly. 2017. "Comparative Politics of Australia and New Zealand.” Oxford Bibliographies. http://www.oxfordbibliographies.com/view/document/obo9780199756223/obo-9780199756223-0008.xml

Sheldon, R. 2010. "The Rehetoric of Future Harm: Representtaionsand Figurations of Child in Contemporary American Discourses of Catastrophe." Doctor of Philosophy thesis, City University of New York.

Sims, M. 2014. "Is the Care-Education Dichotomy behind Us? Should It Be?" Australasian Journal of Early Childhood 39: 3-11.

Sims, M. 2017. "Neoliberalism and Early Childhood." Cogent Education 4: 1-10. https://www. tandfonline.com/doi/pdf/10.1080/2331186X.2017.1365411? needAccess=true

Sims, M., and M. Waniganayake. 2015. "The Performance of Compliance in Early Childhood: Neoliberalism and Nice Ladies." Global Studies of Childhood 5 (3): 333-345. doi:10.1177/ 2043610615597154.

Sims, M., R. Forrest, A. Semann, and C. Slattery. 2014. "Conceptions of Early Childhood Leadership: Driving New Professionalism?" International Journal of Leadership in Education: Theory and Practice 18: 149-166. doi:10.1080/13603124.2014.962101.

Sinclair, K. 1986. A Destiny Apart. New Zealand's Search for National Identity. Wellington: Allen \& Unwin in Association with the Port Nicholson Press.

Smith, R. 1989. 'One United People': Second-Class Female Citizenship and the American Quest for Community." Yale Journal of Law \& Humanities 1 (2): 229-293.

Somerset, G. 1976. Vital Play in Early Childhood. Auckland: New Zealand Playcentre Association.

Soto, L. D., and B. B. Swadener, eds. 2005. Power and Voice in Research with Children. New York: Peter Lang. 
Spoonley, P. 2017. "Renegotiating Citizenship: Indigeneity and Superdiversity in Contemporary Aotearoa/New Zealand." In Citizenship in Transnational Perspective, Politics of Citizenship and Migration, edited by J. Mann, 209-222. Cham: Springer.

Stannard, D. E. 1992. American Holocaust: The Conquest of the New World. Oxford: Oxford University Press.

Stover, S. 2013. "Working Theories on 'Unintended Consequences' of Early Childhood Education in Aotearoa, New Zealand." Australasian Journal of Early Childhood 38: 4-8.

Sumsion, J., and S. Barnes. 2010. "Images of Early Childhood Educators in Belonging, Being and Becoming: The Early Years Learning Framework for Australia." Hong Kong Journal of Early Childhood 8 (2): 34-43.

Sumsion, J., and S. Grieshaber. 2012. "Pursuing Better Childhoods and Futures through Curriculum: Utopian Visions in the Development of Australia's Early Years Learning Framework." Global Studies of Childhood 2 (3): 230-244.

Swadener, B. B., and V. Polakow. 2011. "Introduction to the Special Issue on Children's Rights and Voice in Research: Cross-National Perspectives." Early Education and Development 22 (5): 707-713. doi:10.1080/10409289.2011.597028.

Swain, D. 1995. "Family Group Conferences in Child Care and Protection and in Youth Justice in Aotearoa/New Zealand." International Journal of Law, Policy and the Family 9 (2): 155-207. doi:10.1093/lawfam/9.2.155.

Taylor, A. 2014. "Settler Children, Kangaroos an Dthe Cultural Politics of Australian National Belonging." Global Studies of Childhood 4 (3): 169-182. doi:10.2304/gsch.2014.4.3.169.

Tijsterman, S. 2014. "Global and Cosmopolitan Citizenship." In Handbook of Political Citizenship and Social Movement, edited by H.-A. van der Heijden, 177-201. Cheltenham: Edward Elgar Pub.

U.S. Department of Health and Human Services. 2010. The Head Start Child Development and Early Learning Framework. Washington, DC: Office of Head Start.

U.S. Department of Health and Human Services. 2015. The Head Start Early Learning Outcomes Framework: Ages Birth to Five. Washington, DC: Office of Head Start.

United Nations General Assembly. 1989. United Nations Convention on the Rights of the Child. http://www.un-documents.net/crc.htm

van Krieken, R. 1997. "Sociology and the Reproductive Self: Demographic Transitions and Modernity." Sociology 31 (3): 445-471. doi:10.1177/0038038597031003005.

van Krieken, R. 2010. "Childhood in Australian Sociology and Society." Current Sociology 58 (2): 232-249. doi:10.1177/0011392109354243.

Veracini, L. 2010. Settler Coloniaism: A Theoretical Overview. London: Palgrave MacMillan.

Walker, R. 2004. Ka Whawhai Tonu Matou. Struggle without end. revised ed. Auckland: Penguin.

Walkerdine, V. 1984. "Developmental Psychology and Child Centred Pedagogy: The Insertion of Piaget into Early Education." In Changing the Subject: Psychology, Social Regulation and Subjectivity, edited by J. Henriques, W. Hollaway, C. Irwin, C. Venn, and V. Walkerdine, 148-198. London: Methuen \& Co.

Wanna, J. 2008. "Nation Building in Australia: A Discourse, Iconic Project or Tradition of Resonance?." In Nation Building, Past, Present and Future, edited by J. Butcher, 1-6. Canberra: ANU Press.

Wolfe, P. 2006. "Settler Colonialism and the Elimination of the Native." Journal of Genocidal Research 8 (4): 387-409. doi:10.1080/14623520601056240.

Wood, E., and H. Hedges. 2016. "Curriculum in Early Childhood Education: Critical Questions about Content, Coherence, and Control." The Curriculum Journal 27 (3): 387-405. doi:10.1080/09585176.2015.1129981.

Wyness, M. G. 2000. Contesting Childhood. London: Falmer Press.

Yuval-Davis, N. 2011. Politics of Belonging: Intersectional Contestations. London: Sage. 